ILAN AVISAR

The Steve Tisch School of Film and Television The David and Yolanda Katz Faculty of the Arts, Tel Aviv University
Images vol. XXV/no. 34

Poznań 2019

ISSN 1731-450X

\title{
The national and the popular in Israeli cinema
}

\begin{abstract}
Avisar Ilan, The national and the popular in Israeli cinema. "Images" vol. XXV, no. 34. Poznań 2019. Adam Mickiewicz University Press. Pp. 29-44. ISSN 1731-450X. DOI 10.14746/i.2019.34.02.

The article examines Israeli cinema as a critical participant in the local drama of national ideology and national identity. Israeli filmmakers have engaged in enunciating the national culture, in the context of the medium's history, political ideologies, and the tension between high art and popular culture. The historical review of Israeli films shows dramatic changes over the years from nationalistic propaganda to radical critique and post-Zionism. Israeli cinema appears now to seek a constructive and fruitful dialogue with the viewers. In the recent wave of popular films, the national ideology is more conscious of its past mistakes and inherent deficiencies; its presentation of national identity is less narrow and more open to alternative types, thereby suggesting new vistas of national culture.
\end{abstract}

KEYWORDS: Nationalism, Zionism, Israeli cinema, national cinema, popular culture

The recent revival of the ideology of nationalism and the preoccupation with the subject of national identity has led to new attention to national cinemas.[1] The concept of "national cinema" has become a category of reference in popular discourse and a critical concept similar to the status of auteur, genre, or gender in the analyses of films. National cinemas are no longer regarded as the phenomenon of developing countries, which tend to engage in local, exotic themes, reflecting specific - and marginalized - cultures in relation to the works of leading film artists and the centers of film production in Europe and Hollywood.[2] Rather, in the last three decades, there have been numerous publications on the national dimension in European cinemas, or studies of American cinema as a national cinema. In Film Nation: Hollywood Looks at U.S. History, Robert Burgoyne makes the point that " $[\mathrm{i}] \mathrm{n}$ its range and coverage of the field of national imaginings, the Hollywood cinema is in many ways an unparalleled expression of national culture, one that has molded the selfimage of the nation in pervasive and explicit ways.[3] And Susan Hayward published French National Cinema, with an exemplary introduction that states: "In the writing of a national cinema there are two fundamental yet crucial axes of reflection to be considered. First, how is the national enunciated? In other words, what are the texts and what meanings do they mobilise?

[1] This article is an actualized and expanded version of the paper published in "Shofar: An Interdisciplinary Journal of Jewish Studies" 2005, vol. 24, issue 1.
[2] See: G. Mast, A Short History of the Movies, Indianapolis 1976, ch. 14, "Emerging National Traditions," pp. 403-474.

[3] R. Burgoyne, Film Nation: Hollywood Looks at U.S. History, Minneapolis 1997, p. 6. 
And, second, how to enunciate the national? That is, what typologies must be traced into a cartography of the national?"[4]

The important input of the new critical discourse of national cinema is that it is not simply a study of how filmmaking reflects a specific ideology or serves as an agent of that ideology. Rather, films gain special cultural meaning and added value through their engagement with the explicit concerns of their local audience and the deeper layers of collective fears and desires that inform the drama of national identity. My paper will examine Israeli cinema as a critical participant in the local drama of national ideology and national identity, considering the content and forms of the films along with their social and cultural position in the public discourse. The historical review of Israeli films in terms of their enunciation of the national will show a dramatic narrative of significant changes over the years from a nationalistic propaganda to radical critique and national nihilism, with the possibility of a renewed beginning for Israeli national cinema in the new millennium.

The ideology of nationalism was held in great suspicion following the catastrophic consequences of two world wars in the twentieth century, historical disasters which were viewed as being caused primarily by the unbridled forces of nationalism. With the end of the Cold War in the 1980s, the termination of superpower politics, and the apparent resolution - or suspension - of the ideological conflict between capitalism and socialism, there was a moment of a sense of historical vacuum, popularized by the notion of "the end of history." History, to be sure, continued its course as the narrative of peoples' aspirations and the drama of political conflicts. The most volatile historical force in the post-Cold War era has been nationalism. National aspirations have fueled major confrontations in places like Yugoslovia, territories of the former Soviet Union, Africa, and the Middle East. In the stable and prosperous societies of the First World, the present course of globalization is matched by desire for national identity. The preoccupation of Western Europe with the preservation of national identity within a united Europe runs parallel to the preoccupation of Eastern Europe with securing and finalizing the structure of the nation-state.[5] Michael Ignatieff recalls Freud's assertion on "the narcissism of minor difference" to make the point that "[o]ur identities are based on the small symbols that differentiate us... Cosmopolitans expect Levi's and Benetton, McDonald's and IBM to erode these minor differences. All that happens is that people cling more tenaciously to the deeper differences that remain." [6]

[4] S. Hayward, French National Cinema, London 1993 , p. 5.

[5] Here's one of the opening sentences in "Introduction" to National Identity, ed. K. Cameron, Exeter 1999: "As the European Union becomes more unified through its legislation and interstatal trade and move- ment, there is a centrifugal movement in a number of Member States as individuals begin to feel threatened and to think that they are losing their national identity" (p. 1).

[6] M. Ignatieff, Blood and Belonging, London 1993, p. $10-11$. 
In the contemporary scene of cosmopolitanism or globalization, the United States is a dominant force. The combination of financial fortunes, military might, and the spreading of Hollywood products by the new technologies of communication spurs concern about American imperialism. Anthony Birch noted that "the French and the Americans have been the two peoples [...] most confident that their forms of civilization and their concepts of good government were suitable for export." [7] Susan Hayward refers to political claims of universal values by noting that "universalism, although based in equality, has inherent within it political cultural empire-building. The concept of nation and nationalism becomes, therefore, a concept mobilized in relation to, and as a counteraction against universalism. As an oppositional concept, nation is based in an assumption of difference." [8]

In a recent book entitled Virtual States: The Internet and the Boundaries of the Nation State, Jerry Everard examines the place of nationalism against the background of the global spread of the internet. $\mathrm{He}$ argues that while the new technologies of global communications have diminished the state's role in the goods and service economy, in today's climate of change and uncertainty, people are turning to nationalism and engaging in regional conflicts over identity. The internet's ability to ignore political borders has created, in his words, new needs for boundary-making processes, and ways of identifying the self from the other, "us" from "them".[9]

One of the most influential texts in the recent cultural discourse of nationalism has been Benedict Anderson's Imagined Communities, subtitled Reflections on the Origin and Spread of Nationalism. Anderson's definition of a nation says: "it is an imagined political community and imagined as both inherently limited and sovereign." [10] The notion of "sovereign" is self-evident; in Anderson's words, "nations dream of being free... The gage and emblem of this freedom is the sovereign state" (p. 7). "Limited" it is, because as Anderson put it, "No nation imagines itself coterminous with mankind" (p. 7). Furthermore, the geographical sense of finite boundaries also implies a particularist identity in opposition to claims of universalism. Anderson's critical contribution lies in the notion of an imagined community, which underscores the role of imaginary texts in the construction of national identity. Nationalism, then, is both a quest of peoples to assert their independence - a quest translated into historical events ranging from social reforms to wars and revolutions - and also a source of identity, an identity defined by paradigms of the national culture like myths, values, historical memory, which are expressed by or constructed in narratives, images, and other works of artists and cultural institutions.

[7] A. Birch, Nationalism and National Integration, London 1989, rpt. 2002, p. 13.

[8] S. Hayward, op.cit., p. 3.

[9] J. Everard, Virtual States: The Internet and the Boundaries of the Nation State, London 2000.
[10] B. Anderson, Imagined Communities, subtitled Reflections on the Origin and Spread of Nationalism, 2nd ed., London 1983, p. 6. The source of the quote is in the text. 
In summary, the re-awakened national aspirations of many peoples after the end of the Cold War, the sterility of cyberspace, and the resistance to American hegemony in a globalized world have induced new national sentiments. These sentiments counter the negative assessment of nationalism caused by the wars and the manifest racism of nationalist superiority, further enhanced by social concerns and the ideological approach of multiculturalism, that regarded nationalism as a threat to social pluralism and the respect for the Other. But at the end of the 2oth century, a novel appreciation of nationalism emerged, articulating an agenda that responds to human needs in the new historical situation. Birch notes that the nation-state gives "people a secure sense of identity, status and (usually) pride." [11] Hayward adds: "People look at their state and see themselves in it, and it is precisely this narcissism which keeps them within it. But, as the myth of Narcissus reminds us, this mirror effect has a double edge for it implies both the individuation of the subject (within the state) and the sacrifice of the self (to the state)."[12]

Zionism, the movement of Jewish nationalism, emerged in the nineteenth century from three principal historical forces: the first is the continuous consciousness of living in Exile and the everlasting quest to return to Zion, a quest that found expression in prayers and had been a central feature of the religious culture of Judaism. The second ideological force of Zionism was the need to escape the dangers of antisemitism and to found a national haven for the Jews. This need became urgent with the apparent failure of the Emancipation to end the threats of antisemitism, threats that were manifest in the pogroms in Russia, the Dreyfus affair, and the new forms of political, national, and racial antisemitism that ultimately led to the Holocaust. The third force was the ideological model of modern nationalism as developed in nineteenth-century Europe, which is basically the desire for self-determination, or for sovereignty to preserve national heritage and cultivate specific cultural identity. These three historical forces that shaped $\mathrm{Zi}$ onism correspond to the three elements in Anderson's definition of the nation. The "limited" aspect corresponds to the consciousness of living in Exile and being different; the quest for sovereignty and the dream to be free sprang from the harsh threats of antisemitism; the "imagined" dimension refers to the ideological insistence of Zionism that Jewish identity is primarily a national identity in the terms of shared collective experiences and "historical destiny." The practical conclusion of Zionism was the call to take action to achieve an independent state in the ancient homeland of the people.

From the beginning of Zionism, artists, scholars, and thinkers had a privileged position in the movement of Jewish nationalism. There was no indigenous Jewish national culture, and the popular forms of Jewish culture were based on diaspora experiences or religious prac- 
tices that were not fitted to the needs of a modern state and the modern ideologies of nationalism. The "men of letters" carried out the task of actually defining and enunciating the Jewish national identity, which included expressing the national aspirations for homeland and independence, reviving the Hebrew language, articulating collective memories and shared experiences, and constructing the symbolic texts of national culture, like myths, anthems, folklore, and children stories. Since Zionism did not have a grassroots tradition of popular culture, Anderson's notion of an imagined community is even more salient in the case of Zionism. The discourse of Israeli studies included tracing the construction of national imaginings, which would later be confused with fabrications and falsifications. The confusion between enunciation, construction, and fabrication has rendered Zionist ideology an easy target for deconstruction and destruction by its critics and other detractors of the Jewish state. The deconstructionist efforts occasionally resort to extreme critical attitudes, whose negative ideological zeal is similar in its intensity to the idealistic zeal of the formative years of Zionism.[13]

The course of the Zionist historical enterprise and the modern state of Israel displays dramatic changes in the ideological hold of $\mathrm{Zi}$ onism. In its first fifty years, from the 188 os to the 1930s, Zionism was highly polemical in the Jewish world, debating other ideologies of Jewish existence, like the assimilationists, who placed their faith in the promises of European emancipation; the religious orthodox, who chose to remain "outside history" in passive expectation of the Messiah; the Bundists, who believed that the "Jewish Solution" would take place in the context of a Marxist revolution; or those who favored America as the promised land. Within the Zionist movement, the ideological commitment was usually fervent. The pioneering experience and the revolutionary passion involved in the formation of a "new Jew" were manifest in hard agricultural labor, a collective lifestyle, and struggles with the hardships and threats of the rough conditions in the new ancient land. The genocidal crimes against the Jews in the Holocaust and the establishment of Israel after a heroic struggle for independence marked the ideological victory of Zionism. In the first two decades of its existence, Israel managed to succeed and prosper. The most significant achievements included the absorption of millions of new immigrants, mostly refugees of Hitler's Europe or of Arab countries, cultivating stable democracy, solid economy, and remarkable scientific accomplishment ranging from agricultural methods to space technology, and finally prevailing in the battles against its enemies, culminating in the victory of the Six Day War.

After 1967, Israel enjoyed a few years of euphoria. However, the economic prosperity, privatization, and the new dominance of urban centers led to a decline in the ideals of collectivism, frontier experiences, or a modest lifestyle, ideals that were the backbone of Zionism and

[13] See: Y. Hazoni, The Jewish State: The Struggle for Israel's Soul, New York 2001. 
were identified mainly with the Kibbutz experience. The significant challenges to national unity began to appear with local voices that felt ill at ease with the prevailing moods of triumphalism and expressions of national arrogance. The new considerable interactions with the Palestinian population in the territories brought to the foreground the problems of displacement in 1948 and the occupation after 1967. The Yom Kippur War in 1973, with its near defeat and heavy losses, was a severe blow to national confidence. In the last quarter of the twentieth century, Israel was given to new/old anxieties (the Holocaust complex), searing ideological crises, and deep political polarization.

Israeli cinema has been a part of the cultural forces that have shaped Israeli nationalism. Film as a popular medium enunciates national identity, especially in genres like the western, the historical epic, and the war film. The western, although widely known as a distinctly American phenomenon, has a universal function, marking the genre of films that trace the origins of the nation by celebrating the pioneering phases of settlement and communal formation. The experience of developing a civilized, value-ridden society involves battles against hostile forces of wilderness and human enemies, who are often the indigenous population, presented as primitive inhabitants who need to be vanquished. Israeli westerns include They Were Ten (1960), which marks the beginning of modern Israeli filmmaking, and many films that feature the Kibbutz and its members can also be considered to deal with the western version of Israeli experience.

The historical epic is the genre that gives meaning to historical time, displaying great events and heroic historical figures in a course of events whose final goal is the achievement of national victory. The small film industry of Israel has not produced historical epics; the Israeli cinematic imagining has tended to focus on contemporary local issues, avoiding grand historical visions. But several foreign productions featured epic chapters of Israel history, including Hollywood's biblical epics in the fifties, or American TV series on the Holocaust or on Masada. The most famous production was Exodus (1960), which was a war movie, a local western, and a historical epic in one major film. Exodus - Leon Uris' book and Otto Preminger's film - had enormous impact, inscribing the images of the Jewish state throughout the world for at least two decades (sixties and seventies), images of pioneering society in a kibbutz, valiant fighters for independence, highly just in their national struggle because of the Holocaust, and nearly super-heroes in style, triumphs, and look, as was displayed by the acting of Paul Newman. Ironically, this film exercised an oedipal influence on Israeli cinema. By and large, the artistic sensitivities of Israeli filmmakers shun the heroic presentation of Exodus, dismissing what they regard as a spurious Hollywood approach and phony images. Instead, Israeli filmmakers have chosen to devote their works to exploring the problematic aspects of the Israeli experience, which they regard as the authentic mission of their art. 
War movies are probably the most significant and obvious forms of the national mythology of the nation-state.[14] War movies feature the national struggle for independence, the fights for freedom or survival, rendering the battles as the crucibles of national unity. The war films are often patriotic works, glorifying heroic deeds and paying tribute to distinguished individuals. War movies engage in the construction of the national hero, the model of admirable bravery, camaraderie, devotion to the collective ideals, and readiness to make the ultimate sacrifice for the national goals. In film culture, war movies often produce the great film stars of their society. In Israeli culture, the figure of the heroic Sabra took on a specific shape and look in local war movies that featured "the ideal type." In Israeli cinema, war films form the genre with the most significant volume, and, in my opinion, the most remarkable cinematic achievements. These achievements are the result of the shared experience of military service in Israeli society, the dramatic charge of the historical events, and often the cooperation of the army and political establishment that significantly enhances the production values of war movies. For example, Every Bastard a King featured battle scenes with Israeli tanks and military equipment taken from the Egyptians in the Six-Day war; Ricochets used army helicopters for aerial shots, and was made by recruited talents who made the film as their reserve duty; Operation Thunderbolt had the cooperation of the army in its research for the details of the military operation, and the production included personal appearances by then Prime Minister Rabin and defense minister Peres.

In following the dramatic content and ideological charge of Israel war movies, the story of Israeli cinema from its beginning until the end of the 2oth century can be divided into fairly distinct chapters, which correspond to the ideological movement from enthusiastic nation-building to moral scruples and doubts, leading to radical critique and national negation. By the beginning of the 21st century, there appear new attitudes towards the subject of national ideology and national identity.

The first chapter includes national-heroic films that range from the propagandistic productions of Zionist organizations in the thirties and forties, to the narrative dramas of the fifties and sixties that paid homage to the fight for independence (Hill 24 Doesn't Answer, He Walked in the Fields), Israel's war in the Sinai Campaign (Sinaia), the bombardments of Kibbutzim by Arab armies (Hero's Wife), the Six Day War (Every Bastard a King), and the war against terrorism, culminating in Operation Thunderbolt. These films set up many images of national ideology, including the triumphant narratives of Israel's history, the figure of the heroic Sabra, or the values of frontier pioneering and collective lifestyle as exemplified in the Kibbutz experience. Israeli cinema serves as a national cinema in the sense that the films were articulating the deep sentiments of its public, gaining popularity by the measure of

[14] R. Burgoyne, op.cit., pp. 6-7. 
their success to touch the deep nerves of their audience, and offering reassuring versions of the dominant national ideology, whose consensual grip was challenged only in outstanding texts of high culture (like the literary works of S. Yizhar) or by marginal political groups.

In the seventies, Israeli filmmakers with high artistic ambitions expressed a passionate critique of the popular genres of Israeli cine$\mathrm{ma}$, the national heroic dramas and the romantic comedies known as Bourekas movies, which played on conflicts of ethnic differences that are resolved by the triumph of love in romantic union and the social victory of national unity. The ideological critique targeted the happy-ending dramas that supposedly glossed over the serious problems of social gaps and national tests. The alternative exploration of private lives and personal themes led to a short-lived wave of artistic movies influenced by the models of the European art cinema of the fifties and sixties. By the late seventies, there was an explicit defiance of the burden of national ideology with films that challenge prevailing norms and myths. Judd Ne'eman, a former physician who won a medal for saving soldiers' lives in the Six Day War, directed a military drama, Paratroopers (1978), showing how the brutal training in an elite unit leads to the suicide of a sensitive young man. The military service and training that were formerly viewed as the catalysts of proper maturity, and whose tough ordeals shaped the model of masculine identity, were presented in Paratroopers as the setting of humiliation and human destruction. Ilan Moshinsohn's The Wooden Gun (1979) provides an ironic look at the public culture of heroic tradition. The film shows children playing war games and brutalizing each other, after emulating the war stories they hear from their parents and teachers. Hamsin (Dan Waxman, 1980) is a western-like drama between a Jewish landowner in the Galilee and his Arab worker. It was one of the first films to feature an Arab in a serious dramatic role. The Arab character has an affair with the sister of his Jewish boss, who kills his employee because of the national transgression involved in the romantic connection.

These films led to a spate of political protest films that dominated Israeli cinema in the eighties. The political scene in Israel pitted the filmmakers against the political establishment. The victory of Menahem Begin and the right-wing parties in 1977 placed the Israeli filmmakers and critics - most of whom see themselves as members of the political Left - in direct opposition to the ruling party.[15] The war in Lebanon in the early eighties became highly controversial. The media featured images and stories underscoring the suffering of the Palestinian victims, culminating in the Lebanese massacres in Sabra and Shatila. This was the background for the surprising success of Beyond the Walls (Uri Barabash, 1984). About half a million Israelis watched the prison drama on the development of solidarity between Jewish and Arab prisoners.

[15] Meir Vizaltir mentions the fact that following the elections of 1977, there was a new alienation between the culture community and the institutions and figures of the political powers (Features of our cultural affection," "Politica" 1992, vol. 45 (Fall). 
Heavily melodramatic and unabashedly sympathetic towards the jailed Arab terrorists, the appeal of the film for Israeli viewers was based on the fresh presentation of the Palestinian as a dignified, handsome character; the critique of violent elements in Israeli society; and the vision of cooperation between Israelis and Palestinians.

Since the eighties, there has been a growing radicalization of the political messages, and the themes of solidarity or cooperation eventually have given way to skeptical attitudes and apocalyptic visions. In the first phase, several films address the political situation in the form of love stories between Arabs and Jews, as in A Very Narrow Bridge, the story of a military prosecutor who falls in love with a woman from Ramallah, whose brother is a member of the PLO. By contrast, Crossfire is based on a true incident, the love affair between a Jewish girl and an Arab from Jaffa during the War of Independence. Its ending is the execution of the Jewish girl by members of the Jewish underground. The later metaphor for the possibility of coexistence is the ironic title The Smile of the Lamb, an adaptation of David Grossman's novel, on the dire consequences of the so-called "enlightened occupation." The initial observation on the effects of national militarism on children's behavior (Wooden Gun) is replaced with a nightmarish vision on the creation of human monsters by military aspirations. Night Soldier is the story of the son of a high officer who is rejected from the army for health reasons and becomes a serial killer of soldiers on the roads. The parody of educational ceremonies through children's eyes in Wooden Gun changes into the presentation of the memorials for the fallen soldiers as a cynical financial enterprise in The Vulture.

Another principal site of national expression is the presentation of local characters. Hayward refers to local actors as screen agents characterized by "the gesturality and the morphology of the body, gestures, words, intonations, attitudes, postures - all of these separate them, thus affirming the plurality of the cultures." [16] Another critical concept is the "the star as sign." As a narrative art and a visual medium, cinema articulates the goals and conflicts of a nation through representative characters. The protagonists of film narratives, who become the movie stars of their society, personalize social meaning and ideologies. The stars project a self-image of society, or national identity, in their appearance, mode of behavior, values, and actions. [17] The heroic national films featured an ideal image of the Sabra, "young, healthy, and fresh," good looking, powerful, superior to all other characters. Assie Dayan epitomized the "ideal type" in the role of Uri, the hero of He Walked in the Fields. Yehoram Gaon was another screen hero, in playing the characters of Kazablan, Yoram in Every Bastard a King, and Yoni Netanyahu in Operation Thunderbolt. In the political protest films the Israeli protagonist undergoes a transformation. The former heroic Sabra soldier is now physically and mentally damaged. Don't Give a Damn 
and Hemo, King of Jerusalem focus on the physical impotence inflicted by war; Battle Shock and Burning Memory are on the neurotic behaviors of wounded soldiers; in Where Eagles Fly, an exemplary Israeli hero a pilot - is dying of cancer. In the presentation of the protagonist's relationships with other characters, the dominant themes are of weakness, frustration, disintegration, and decline. Families and friendships fall apart under the pressure of political complications. Green Fields features three generations of an Israeli family whose internal tensions and animosities surface when their vehicle is stoned by Palestinians; in One of Us, former buddies from an elite unit confront each other as one becomes an interrogator of the other, charged with the killing of a Palestinian prisoner.

Between 1977 and 1990, the political cinema was the dominant mode of Israeli filmmaking, totaling over fifty films.[18] Ironically, most of the political protest films were made with government subsidies, through the Fund for the Promotion of Israeli Quality Films. The Fund started to operate in 1978 , and it practically released the filmmakers from their dependence on viewers by supporting productions with public money.[19] The freedom given to the filmmakers was exploited to make sharp political statements. One should also add that the political films were made in a climate that gave them full support from other quarters of the cultural milieu, be it critics and teachers in film schools, or the texts of Hebrew literature, theatre, and art exhibitions that actually addressed most of the issues in a similar fashion.

The Israeli cinema of those years betrays a serious crisis in the national ideology of the Israelis. The effects of historical events and political processes (the Yom Kippur War, the rise of Palestinian na-

[18] The only remarkable exception was Ricochets (1986), a production of the Israeli army on the war in Lebanon. The initial intention was to create an educational drama, solely for the internal use of the military, on proper conduct in battle situations against terrorists amidst civilian population. The final result was a conventional war melodrama on the experience of Israeli soldiers in Lebanon. The film was impressive in production values thanks to the contribution of the military (ranging from allocating helicopters for aerial shots to drafting the principal actors to appear in the film as their reserve duty). Ricochets was seen by nearly one million viewers and became the most popular film of the decade. However, a public committee of prominent people from the film industry, appointed to select the film that would represent Israel in the Oscar competition of best foreign film, chose Avanti Popolo, a student project that developed into a brilliant revisionist war drama, on the plights of two Arab soldiers in the Six Day War.

[19] During the phase of the political protest films of the eighties, Israeli filmmakers lost the Israeli audience but enjoyed some popularity in international film festivals. Most often, the foreign reception to the films has been symptomatic of the international political climate. Israeli filmmakers (Beyond the Walls) arriving at Italy to participate in film festivals were met with incredulous Italians, wondering how they managed to smuggle the films outside the country. In Denmark, reviewers expressed their shock and outrage at the display of self-hatred. French and German televisions proved to be generous supporters, rewarding the filmmakers for the rights to show critical portrayals of Israel to their spectators. In America, Jewish communities throughout the continent usually shunned these films. They were screened in New York and Los Angeles to mostly Israeli expatriates, generally receiving negative reviews from the professional critics of the local newspapers. See: D. Fainaru, Inside story, "Sight and Sound, Maps and Dreams: Palestine/Israel" 1992, Spring, p. 15. See also: E. Edelsten, Self-Hatred in the Guise of Political Message, "Maariv" 1986, February 11. 
tionalism), polarization in the social scene, and novel attitudes towards private profits and personal gratifications have weakened the ideological grip of nationalism. Zionism, which was formerly held as a highly burdening concept because of its ideological demands and indoctrination, has moved from the spheres of comic critiques to labored arguments on its falsity and fierce attacks from anti-Zionists or post-Zionists. The critical tone regarding Israeli cinema was set by the first academic study of the subject, Ella Shohat's Israeli Cinema: East/West and the Politics of Representation, published in 1989. A disciple of Eduard Said, Ms. Shohat contends that Israeli films reflect the colonial nature of Zionism, especially the oppression of the Jews who came from Arab countries and the Palestinian Arabs. Her conclusion:

Israeli cinema, like Israeli society, remains haunted by the East in the form of the Palestinian question. Elided, distorted, or idealized by the early films of the heroic-nationalist phase, the Palestinian issue has been confronted, albeit timidly, only in the eighties. Even the eighties 'political' films, as we have seen, tend to merely translate the identity dilemmas of Sabra protagonists rather than purvey a truly oppositional voice. Too often the films betray a kind of failure of intellectual nerve, a paralysis of the political imagination, a refusal to radically supersede the exhausted paradigms supplied by the Zionist master-narrative.[20]

Shohat's book had a great influence on academic studies of Israeli cinema. For several years after its publication it was the only scholarly book on the subject, and its anti-Zionist thrust was well received in many Israeli circles, including film critics, scholars, and teachers. Shohat divided the history of Israeli cinema into distinct phases, following the change from the national heroic movies of the early years to the political protest films of the eighties. The overall picture is of an evolution from simplified nationalistic texts to movies dealing with formerly repressed subjects, a progressive narrative from the initial flag-waving propaganda to critical works that fall short of superseding "the Zionist master-narrative." [21]

The phase of the political protest films from the late seventies through the eighties displays a radicalized ideological process from anguished critique or passionate "slaughter of holy cows" to the point of complete negation of any value associated with the national. The nihilistic posture was not accompanied by any constructive visions or alternative ideologies. [22] The result was a serious crisis in Israeli

[20] E. Shohat, Israeli Cinema: East/West and the Politics of Representation, Austin 1989, p. 272.

[21] The films of the national-heroic phase were more complex than they appeared to be, especially the popular films of the sixties that expressed social tensions and ideological contradictions through their popular narratives. In her recent book, Nurith Gertz makes the point that while the early films can be viewed as simplified propaganda instruments of Zionist ideolo- gy, they also contain many cracks and contradictions in their optimistic structure and imply suppressed stories of alternative narratives. See: N. Gertz, Makhela Aheret (Holocaust Survivors, Aliens and Others in Israeli Cinema and Literature), Tel Aviv 2004, p. 89. [22] Nurith Gertz noted that the political criticism of the films in the eighties did not offer any alternative ideas or constructive options. See: N. Gertz, Historical Memory: Israeli Cinema and Literature in the 
cinema of failed films and loss of connection with its audience. The narratives of fall and disintegration, the presentation of broken protagonists and pathetic anti-heroes, pictorial presentation that betrayed rejection or dislike of the local landscapes, all these attitudes in the context of explicit denials of the ideological foundations of national identity led to a reluctance on the part of the Israeli public to view Israeli films. The end of the political protest films occurs in the nineties, after numerous films seemed to repeat themselves. Besides, after envisioning Israel in a second Holocaust created by Jewish nationalists (The Road to Ein Harod), or the presentation of child survivors arriving at the promised land, suffering ordeals that recall their Holocaust horrors and at the end fly into the sky praying to reach another land (New Land), the possibilities of imaginative innovations and radical critique seem to have been exhausted. In addition, Israeli television and newspapers have engaged in active criticism of government policies, rendering the cinematic dramas on the same issues redundant. Israeli filmmakers withdrew to personal films, detaching the movies from the national drama, or to social dramas with social criticism. In contrast with the romantic comedies of the sixties and seventies - the Bourekas movies which featured the victory of youthful love over ethnic differences and celebrated the triumphant unity of the Jewish nation, the new social dramas of ethnic traditions were devoid of any unifying aspects of national ideology (Shchur, Afula Express, Love Sick from Nana Street). Other films presented the affluent aspects of a society that made the move to capitalism, urbanism, and private hedonism, with the former ideals of socialism, collectivism, frontier adventures, and military nationalism becoming atavistic forces of destruction (Life According to AGFA), or they are simply totally absent (Tel Aviv Stories).

The preoccupation with personal, intimate worlds, or with ethnic identity and urban identity marks a deliberate withdrawal from engaging with the national drama. The personal film is often a product of the modernist attention to the internal world of the human personality. In Israeli culture, the national-heroic films were viewed as simplified, propagandistic, and anachronistic, out of line with the progress of art and culture into modernism. This view reflects the entrenchment in the cultural mood of the sixties and seventies, in the preference for European art cinema and American filmmaking of these decades that were a product of the political crisis and social upheavals in America. But in the United States, the brooding modernist works of these decades, the dramas that challenged social ills, and even the Vietnam war movies of the late seventies retained a degree of American self-affirmation. Eventually, American cinema rediscovered the values of nationalism, militarism, and heroism in the Reagan years of the eighties, which continued well into Bill Clinton's nineties. The tormented, doubtful anti-hero

1980s and 1990s, [in:] Critical Essays on Israeli Society, Religion, and Government, eds K. Avruch, W. Zenner, Albany 1997, pp. 209-226. See also: I. Avisar, Israeli cinema and the ending of Zionism, [in:] Israel in the Nineties, eds F. Lazin, G. Mahler, Gainesville 1996, pp. 153-168. 
protagonists of the sixties and seventies were replaced with new types of national heroes (Rambo movies), military heroes (Richard Gere in An Officer and a Gentleman, or Tom Cruise in Top Gun), epic heroes (Mel Gibson in Braveheart), and super-heroes (Arnold Schwarzenegger or Superman). Usually, Israeli critics and filmmakers disdainfully rejected these new popular movies, although several Israeli filmmakers moved to the United States in those years and produced numerous B movies that were heroic war adventures with strong nationalist politics.[23]

By contrast, many members of Israel's circles of high culture especially in the arts, and several vocal academic forces - have adopted more extreme positions against Jewish nationalism. Some regard the course of Zionism as a cardinal sin against the indigenous Arabs. Others consider Zionism as a national ideology with demands that crush the values of individuality ("the sacrifice of the self to the state"). Many anti-Zionists in Israel escape the apparent contradiction of their identity by clinging to the universal imperatives of Jewish ethics and civilization, expressing content in being citizens of Jewish origin in a civilian society rather than a nation-state. There is a vast body of literature in Israel, mostly identified with the writings of the so-called post-Zionists, that seeks to systematically undermine any basis of Jewish nationalism in Israel in revisionist writings ranging from the validity of biblical archeology to recent events in Israel history. Consequently, the Zionist master-narrative of the national return to the ancient homeland and the heroic struggles for survival and independence has been seriously challenged, often replaced by a post-colonial ideology that views the story of the modern Jewish state as an act of western colonization and displacement of Arabs.

During the last three decades, Israel has been in a course of ominous polarization, leading to volatile rhetoric, violent acts, and the radicalization of ideological positions. The ideological energies of Jewish nationalism persisted mostly in popular texts and the lower classes of Israeli society. When it comes to the affirmative acts of national sentiments, collective narratives, heroic deeds, or even the simple expressions of love and attachment to the local landscapes, one finds these affirmative acts in the spheres of popular culture.

The tension between high culture and popular culture is a central element in the history of cinema as a medium and cultural form. Generally, art cinema boasts cultural prestige, while commercial cinema enjoys the vast resources of mass culture. In the book Dreaming Identities, Elizabeth Traube explicates the two poles of the debate over mass culture:

At one point of that debate mass culture is viewed as the property of its producers, the elites who control what have come to be known as the culture industries. In this viewpoint, developed by the cultural critics of the Frankfurt School and also represented in the Althusserian-Lacanian

[23] The most famous Israeli filmmaker in Hollywood in the eighties was Menahem Golan, who produced the Operation Thunderbolt - inspired series Delta
Force, and the Rambotype war movies with Chuck Norris. 
paradigm as applied to film studies, mass culture appears as an instrument for ideological manipulation, a form of social control through which false or inauthentic beliefs are reinforced and inculcated in audiences. At the other pole, where the reference is usually to 'popular culture', the object of study is viewed as the property of receiving audiences and taken as a faithful expression of collective beliefs and values.[24]

Cinema has been a force that has challenged the rigid divisions between high and popular culture, sometimes blurring the distinctions, in some cases bridging the gaps. In particular, national cinema functions as a cultural arena that is nourished from the interaction of popular and art cinema. Popular culture, especially when viewed as an evocation of collective memory and tradition, is the site of contemporary social engagement with history, and hence the articulation of national identity. National cinema features mythic narratives, exemplary figures, and the treatment of issues and phenomena that enunciate the national identity of the local culture. On the other hand, critics of nationalism mobilize cultural elitism to foster political arguments, dismissing the value of popular culture as a lowly form of ideological manipulation. The prominent Israeli artists and authors of the last three decades took upon themselves to be the critical voices of their society (occasionally recalling or explicitly identifying with the role of the biblical prophet), challenging national premises and expressing suspicion towards any gesture of national collectivism. Consequently, in the past three decades, the energies that have sustained Israel as a Jewish nation-state have not come from its artists and authors. Popular culture has become the principal reservoir of national sentiments.

When Israeli filmmakers chose to shun any popular expectations and to commit their work to an assault on popular national convictions, the result was a rupture between the filmmakers and their films and the Israeli audience. During the eighties and the nineties, many Israelis developed the attitude that they don't go to see Israeli movies. The two films that collected the most prizes of Israel's film academy in 1999 brought only about 10,000 viewers to the movie theaters. On the other hand, Israeli movies became popular on television and in DVD, but significantly, they were films from the sixties and seventies, mostly low-brow social comedies (Charley and a Half) or military comedies (Givat Halfon Doesn't Answer), becoming nostalgic texts that underscored the desire for old patterns of national culture.

However, since the year 2000, there has been a significant change in Israeli cinema. Late Wedding (2001), Broken Wings (2002), and Nina's Tragedies (2003) were highly successful at the local box office, reclaiming the bond between the filmmakers and their local audience. While these films do not deal directly with national themes, the former bitter critical tone and narcissistic detachment from the local reality have changed

[24] E. Traube, Dreaming Identities: Class, Gender, and Generation in 1980's Hollywood Movies, London 1992, p. 4. 
to compassionate attitudes towards the characters and their settings. Their proven success has initiated new constructive dialogue between Israeli filmmakers and their audience, leading to conditions for new popular cinema that can approach what Traube called "the property of receiving audiences and taken as a faithful expression of collective beliefs and values." The result of this process is a change from national negation or autistic auteurism to new explorations of national values. In 2004, there were nearly ten films with good potential for commercial success. These films are also remarkably varied. The greatest hit of the year, Turn Left at the End of the World (450,00o viewers), is a nostalgic ethnic social comedy about an encounter between Moroccan and Indian Jews in a small town in the Israeli desert. The ending features a unifying reconciliation between the two groups, and the final catharsis involves the drafting of a young immigrant girl into the army. Ushpizin (Guests, 200,000 viewers) is the drama of a new believer in an orthodox neighborhood in Jerusalem, visited by old friends from his criminal past. In contrast with earlier films that were critical of the religious world of orthodox Jews in Israel, in this film, the protagonist and his wife undergo dramatic tests that ultimately vindicate their religious faith. Medurat Hashevet (Camp Fire) is about the ordeals of a mother and her two daughters who desire to join a settlement. The film provides a humoristic look at Israel's religious nationalists - in contrast with more hateful critical attitudes that one is likely to find in texts of the Israeli Left - and follows with sensitivity and compassion the struggles of the mother and her two daughters with their female identities and personal passions in a highly conformist society. Metallic Blues is a road movie about two Israelis who go to Germany to sell an old American car at great profit. The two buddies encounter different situations that compel them to wrestle with their national identity as Israelis and Jews, who are visiting the country responsible for the Holocaust. The most remarkable film of the year is possibly Walk on Water, a thriller involving a Mossad agent hunting an old Nazi. Achieving high qualities of mainstream cinema in the writing, directing, and acting, the film presents an Israeli hero, a fighter who kills a leading terrorist in the opening scene, assigned to locate the man who was responsible for the deaths of members of his own family in the Holocaust. He associates with the suspect's grandson, and in the process, becomes his guide in Israel, a narrative motivation to present the beauty of Israel's landscapes. As it turns out that the German youth is homosexual, the Israeli character is compelled to question his macho concepts of masculine identity. At the end, the Israeli protagonist is unable to carry out the execution. It is the young German who kills his grandfather, and the emotional Israeli character lies in his lap in a pietà pattern. In summation, this mainstream secret agent war thriller contains a curious twist with respect to the generic conventions about the dramatic hero, and in the context of Israeli cinematic iconography, Walk on Water examines significant cracks in the image of the Israeli Sabra hero. 
After completing a full circle from initial nationalistic propaganda to apocalyptic visions of national disintegration, Israeli cinema appears now to be at a fresh beginning, seeking a constructive and fruitful dialogue with Israeli viewers by exploring different aspects of the national culture. In the new cultural discourse of Israeli filmmaking, the national ideology is more conscious of its past mistakes and inherent deficiencies, and its presentation of national identity is less narrow and more open to alternative types, [25] thereby suggesting new vistas of national culture and promising an exciting future for Israeli cinema.

B I B L I O G R A P H Y
Avisar I., Israeli cinema and the ending of Zionism, [in:] Israel in the Nineties, eds F. Lazin, G. Mahler, Gainesville 1996

Avisar I., Visions of Israel: Israeli Filmmakers and Images of the Jewish State, The Jewish Media Fund, c/o Charles H. Revson Foundation, New York 1997 [Second, revised edition, 2002]

Avisar I., The Israeli Scene: Language, Cinema, and Discourse (in Hebrew), Ramot 2005

Avisar I., The Israeli scene - political criticism and the politics of anti-zionism, [in:] Resurgent Antisemitism, ed. H. Alvin Rosenfeld, Bloomington, 2013, pp. 362-381

Avisar I., The Holocaust in Israeli cinema as a conflict of survival and morality, [in:] Identities in Motion, eds M. Talmon, Y. Peleg, Austin 2011, pp. 151-168

Avisar I., Dancing Solo in the Lebanese Mud, (review of "Waltz with Bashir", 2008)

[in] The Wandering View: Modern Jewish Experiences in World Cinema, ed. L. Baron, Lebanon 2011, pp. 358-365

Benedict Anderson, 2nd ed. London 1983

Birch A., Nationalism and National Integration, London 1989

Burgoyne R., Film Nation: Hollywood Looks at U.S. History, Minneapolis 1997

Dyer R., McDonald P., Stars, London 1998

Edelsten E., Self-Hatred in the Guise of Political Message, "Maariv" 1986, February 11

Everard J., Virtual States: The Internet and the Boundaries of the Nation State, London 2000

Fainaru D., Inside story, "Sight and Sound, Maps and Dreams: Palestine/Israel" 1992, Spring

Gertz N., Historical Memory: Israeli Cinema and Literature in the 1980s and 1990s, [in:] Critical Essays on Israeli Society, Religion, and Government, eds K. Avruch, W. Zenner, Albany 1997

Gertz N., Makhela Aheret (Holocaust Survivors, Aliens and Others in Israeli Cinema and Literature), Tel Aviv 2004

Hayward S., French National Cinema, London 1993

Hazoni Y., The Jewish State: The Struggle for Israel's Soul, New York 2001

Ignatieff M., Blood and Belonging, London 1993

Mast G., A short history of the movies, "Emerging National Traditions," 1976, pp. $403-474$

National Identity, ed. K. Cameron, Dexter 1999

Shohat E., Israeli Cinema: East/West and the Politics of Representation, Austin 1989.

Traube E., Dreaming Identities: Class, Gender, and Generation in 1980's Hollywood Movies, London 1992

Vizaltir M., Features of our cultural affection, "Politica" 1992, vol. 45 (Fall)

[25] See N. Gertz, Makhela Aheret... 